\title{
A Study on Primiparous Sows of the Ability to Show Standing Oestrus and to Ovulate after Weaning. Influences of Loss of Body Weight and Backfat during Lactation and of Litter Size, Litter Weight Gain and Season
}

\author{
By Marie Sterning, Lotta Rydhmer, Lena Eliasson, Stig Einarsson and Kjell Andersson \\ Department of Obstetrics and Gynaecology and Department of Animal Breeding \\ and Genetics, Swedish University of Agricultural Sciences, Uppsala, Sweden.
}

\begin{abstract}
Sterning, M., L. Rydhmer, L. Eliasson, S. Einarsson and K. Andersson: A study on primiparous sows of the ability to show standing oestrus and to ovulate after weaning. Influences of loss of body weight and backfat during lactation and of litter size, litter weight gain and season. Acta vet. scand. 1990, 31, 227-236. - The ability to show standing oestrus and to ovulate within 10 days of weaning was studied in 240 purebred Swedish Yorkshire primiparous sows, fed according to a conventional feeding regime during lactation. The sows were weighed and backfat depth was recorded at farrowing and at weaning. Oestrus control was performed daily and blood samples for determination of plasma progesterone were drawn regularly in 205 sows.

The distribution among the sows of the first standing oestrus after weaning had 2 peaks. The first peak occurred within 10 days of weaning and the second 24-30 days after weaning.

Twelve per cent of the sows ovulated without showing standing oestrus within 10 days of weaning and $4 \%$ had an anovulatory first oestrus within the same time. Significant differences in age at farrowing and in loss of weight and backfat during lactation were found between sows which both showed standing oestrus and ovulated within 10 days of weaning and sows which neither showed standing oestrus, nor ovulated within the same time. The season during which weaning occurred significantly influenced the ability to show standing oestrus and ovulate within 10 days of weaning.

Among the sows which both showed standing oestrus and ovulated within 10 days of weaning, significant positive correlations were found between weight loss, litter size, litter weight gain and the interval from weaning to first standing oestrus.
\end{abstract}

heat; progesterone; body composition.

\section{Introduction}

Sows do not normally show oestrus and ovulate during lactation (Kunavongkrit et al. 1982). After weaning the follicular development starts very rapidly, culminating in standing reflex and ovulation (Rojanasthien et al. 1987). In sows expressing their first oestrus within 1 week of weaning, the plas- ma concentration of oestradiol-17 $\beta$ in the utero-ovarian vein started to increase 24-56 $\mathrm{h}$ after weaning (Rojanasthien 1988).

Anoestrus in the sows is a big problem for breeders. Only 45 to $60 \%$ of the primiparous sows express their first oestrus within 7-10 days of weaning (Einarsson \& Setter- 
gren 1974, King 1978, Benjaminsen \& Karlberg 1981).

Many factors influence the ability to regain cyclic activity after weaning, for instance parity number (Einarsson \& Settergren 1974), lactation length (Cole et al. 1975) and season (Aumaitre et al. 1976, Benjaminsen \& Karlberg 1981). Several authors have shown a great influence on oestrus after weaning of nutrition during lactation (Reese et al. 1982, 1984, King \& Dunkin 1986). In these studies both high and low feeding regimes have been used, resulting in smaller or greater loss of weight and backfat, and shorter and longer intervals from weaning to first oestrus, respectively. It is, however, important to investigate the variations in the interval from weaning to oestrus among sows fed according to a conventional feeding regime and to study the relationships between this interval and loss of weight and backfat in these sows.

Benjaminsen \& Karlberg (1981) showed, by means of plasma progesterone determinations, that several sows ovulated without showing a standing reflex. The number of sows in the investigations cited above which ovulated at their first oestrus after weaning is not known. Progesterone determinations both before and after the first oestrus therefore seem to be of great importance.

In this investigation, primiparous sows fed according to a conventional feeding regime during lactation, were used to study:

- the interval from weaning to first standing oestrus.

- the occurrence of ovulation without standing oestrus and the occurrence of standing oestrus without ovulation.

- the influence of body weight loss, backfat loss, litter size, litter weight gain and season on the ability to show standing oestrus and to ovulate within 10 days of weaning.
- the effect of the above-mentioned factors on the interval from weaning to first oestrus in sows showing standing oestrus and ovulating within 10 days of weaning.

\section{Material and methods}

This study comprised 240 purebred Swedish Yorkshire primiparous sows, all with a lactation length of 40-51 days. They belonged to the first 3 generations of a selection experiment for lean tissue growth rate (25-90 $\mathrm{kg}$ ) at 2 different protein levels (Stern 1987), carried out at a research station belonging to the Department of Animal Breedings and Genetics.

The animals were reared in batches and each generation included 3 batches. From 90 $\mathrm{kg}$ live weight they were fed $2.2 \mathrm{~kg} /$ day of a barleybased sow diet. The diet is presented in Table 1.

The gilts in one batch were all mated during a 4 week period. During gestation the gilts

Table 1. Formulation and calculated composition of the sow diet.

\begin{tabular}{lr}
\hline Ingredients & $\%$ \\
\hline Barley & 62.1 \\
Oats & 10.0 \\
Wheat & 15.0 \\
Soya meal & 6.0 \\
Fish meal & 1.5 \\
Meat meal & 2.0 \\
Limestone & 0.7 \\
Monocalcium phosphate & 1.3 \\
Sodium chloride & 0.4 \\
Vitamin & 1.0 \\
& 100.0 \\
Digestible energy, MJ/kg & 12.1 \\
Crude protein & 14.5 \\
Lysine & 0.64 \\
Methionine + Cystine & 0.51 \\
Ca & 0.88 \\
P & 0.66 \\
\hline
\end{tabular}


were kept indoors with 4 animals in each pen. Three weeks before expected farrowing the gilts were moved to individual farrowing pens. After weaning the sows were moved back to the gestation units. Boars were always present in these stables.

During gestation the gilts were fed 2.2 $\mathrm{kg} /$ day of a sow diet described in Table 1). During lactation the daily feed allowance was gradually increased for 2 weeks, from $2.0 \mathrm{~kg}$ at farrowing to a maximum of $2.0 \mathrm{~kg}$ $+0.4 \mathrm{~kg}$ per piglet. After weaning the daily feed intake was 4-5 $\mathrm{kg}$, until mating and thereafter $2.2 \mathrm{~kg}$.

The sows were weighed and ultrasonic measurement of the backfat was made within 2 days of farrowing and weaning. Measurement of the backfat was made at the last rib on both sides, approximately $8 \mathrm{~cm}$ from the middle of the back. The piglets were weighed at birth and at 3 and 6 weeks of age. After weaning oestrous control was performed once daily and the interval from weaning to first oestrus (IWO) was recorded.

Blood samples for determination of plasma progesterone were drawn at 12 days after weaning, if no oestrous symptoms were seen by day 10 after weaning, or 12 days after the first standing reflex, if this occurred within 10 days of weaning. The level of plasma progesterone was determined using a radioimmunoassay system (Bosu et al. 1976) at the Department of Clinical Chemistry, Swedish University of Agricultural Sciences, Uppsala, Sweden. The system used was designed to cower a wide range of progesterone levels, resulting in somewhat poorer assay sensitivity. In this assay system a progesterone concentration $>7 \mathrm{nmol} / \mathrm{l}$ indicates active luteal tissue in the ovaries (Eliasson 1989). When the ability to ovulate was analysed, 35 sows were excluded due to insufficient blood samples.

\section{Statistical analysis}

The statistical analyses were made using the Statistical Analysis System (SAS Institute Inc. 1985). The model used to calculate correlations and least squares means included the effect of batch. When the weaning season was studied the effect of batch was not included, as these 2 variables were confounded. The effect of season was tested by chisquare analysis. The selection line had no effect on the traits studied and has not been included in the model.

The following levels of significance were used:

n.s. $=\mathrm{p}>0.05 ;^{*}=\mathrm{p} \leq 0.05 ;^{* *}=\mathrm{p}$ $0.01 ;{ }^{* * *}=p \leq 0.001$.

\section{Results}

Of the 240 sows studied 145 (60.4\%) showed their first oestrus within 10 days of weaning.

Twenty sows were allowed to show 3 oestruses before they were mated. The mean length of their 2 cycles were 19.6 and 20.0 days, respectively. In 4 sows both cycles were of the same length, while in 10 sows there was a difference of only 1 day between the cycles. Four sows had a difference be-

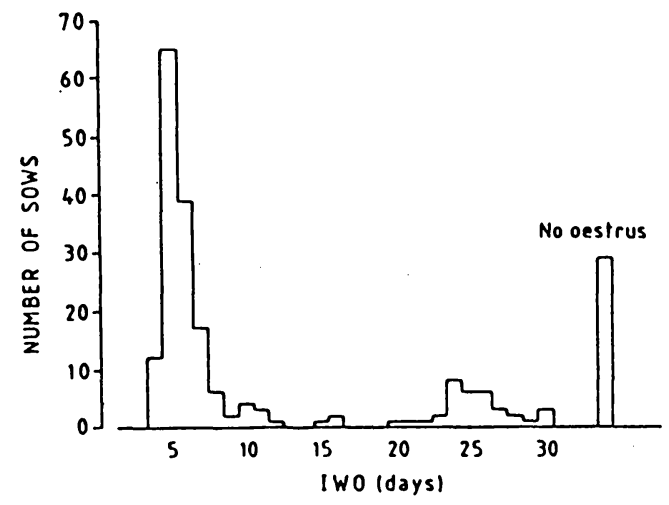

Figure 1. The distribution pattern of the first standing oestrus within 30 days of weaning. IWO = Interval from weaning to first oestrus. 
Table 2. Reproductive and other individual traits in the blood-tested primiparous sows.

\begin{tabular}{lrrc}
\hline & $\mathrm{n}$ & Mean & Stand.dev. \\
\hline $\begin{array}{l}\text { Age of farrow- } \\
\text { ing (days) }\end{array}$ & 205 & 409.8 & 16.8 \\
$\begin{array}{l}\text { Lactation } \\
\text { length (days) }\end{array}$ & 205 & 45.5 & 3.1 \\
$\begin{array}{l}\text { Weight loss during } \\
\text { lactation (kg) }\end{array}$ & 203 & 35.5 & 16.0 \\
$\begin{array}{l}\text { Weight at } \\
\text { weaning (kg) }\end{array}$ & 205 & 163.0 & 20.0 \\
$\begin{array}{l}\text { Backfat loss during } \\
\text { lactation (mm) }\end{array}$ & 202 & 8.9 & 4.2 \\
$\begin{array}{l}\text { Backfat at } \\
\text { weaning (mm) }\end{array}$ & 203 & 15.8 & 5.1 \\
$\begin{array}{l}\text { Litter size } \\
\text { - at birth }\end{array}$ & 205 & 10.4 & 2.8 \\
- born alive & 205 & 9.6 & 2.7 \\
- at 3 weeks & 205 & 8.8 & 2.7 \\
- at 6 weeks & 205 & 8.7 & 2.7 \\
Litter weight gain & & & \\
- 0-3 weeks (kg) & 205 & 40.8 & 10.8 \\
- 0-6 weeks (kg) & 205 & 83.6 & 20.8 \\
\hline
\end{tabular}

tween cycles of 2-4 days while in 2 sows there was a difference of more than 4 days (5-9) between the 2 cycles.

Two hundred and fifteen sows were observed up to 30 days after weaning. The distribution of their IWOs over time is presented in Fig. 1. Twenty-nine sows did not show standing oestrus within 30 days. As can be seen in Fig. 1 the distribution of the IWO has 2 peaks. The first peak occurred within 1 week of weaning and the second about 3 weeks later.

Table 3. Number of sows showing standing oestrus and ovulating within 10 days of weaning.

\begin{tabular}{|c|c|c|c|}
\hline \multirow[t]{2}{*}{$\begin{array}{l}\text { Ovulation within } \\
10 \text { days of } \\
\text { weaning }\end{array}$} & \multicolumn{2}{|c|}{$\begin{array}{l}\text { Standing oestrus } \\
\text { within } 10 \text { days } \\
\text { of weaning }\end{array}$} & \multirow[t]{2}{*}{ Total } \\
\hline & Yes & No & \\
\hline Yes & 123 & 24 & 147 \\
\hline No & 8 & 50 & 58 \\
\hline Total & 131 & 74 & 205 \\
\hline
\end{tabular}

Overall means for reproductive and other individual traits of 205 sows, bloodsampled for progesterone, are presented in Table 2 . The number of sows showing standing oestrus and ovulating within 10 days of weaning are presented in Table 3 .

Twenty-four sows $(11.7 \%)$ ovulated within 10 days of weaning without showing standing oestrus $(O)$. Seventeen of these sows, observed for 30 days or more after weaning, showed standing oestrus at day 23 or later.

Eight sows $(3.9 \%)$ showed standing oestrus without ovulation $(S)$, within 10 days of weaning. They are individually presented in Table 4. None of them were mated on their first standing oestrus. Six sows showed a second standing oestrus and were then mated. Two of the mated sows did not get pregnant. Fifty sows $(24.4 \%)$ neither showed standing oestrus nor ovulated within 10 days of weaning (NSO). Thirty-eight of these sows showed standing oestrus later than 10 days after weaning. Post mortem examination revealed luteal tissue in 6 out of 8 sows which never showed standing oestrus. Both standing oestrus and ovulation within 10 days of weaning were recorded in 123 sows $(60.0 \%)$ (SO). Their mean interval from weaning to first oestrus was 5.6 days $(\mathrm{SD}=$ 1.1 days). Table 5 presents mean values for loss of weight and backfat, litter size and litter weight gain and correlations between these traits and the IWO. There was a significant positive correlation between weight loss during lactation and the IWO ( $\mathrm{p} \leq$ 0.05 ). No significant differences in backfat loss during lactation were found between sows with different length of the IWO. The positive correlations between litter size at birth (alive and stillborn) and at 3 and 6 weeks and the IWO were significant. The number of piglets born alive did not differ significantly between sows with different IWO length. The interval from weaning to 
Table 4. Individual presentation of the 8 S-sows.

\begin{tabular}{lcccccccc}
\hline Sow number & 1 & 2 & 3 & 4 & 5 & 6 & 7 & 8 \\
\hline $\begin{array}{l}\text { Interval from } \\
\text { weaning to } \\
\text { first oestrus } \\
\text { (days) }\end{array}$ & 4 & 5 & 6 & 6 & 6 & 6 & 8 & 10 \\
$\begin{array}{l}\text { Length of } \\
\text { cycle (days) }\end{array}$ & 19 & 19 & 17 & 13 & - & 32 & - & 21 \\
$-\begin{array}{l}\text { 1st to 2nd } \\
\text { oestrus }\end{array}$ & - & - & - & - & - & 19 & - & 22 \\
$-\begin{array}{l}2 \text { nd to 3rd } \\
\text { oestrus }\end{array}$ & yes & yes & yes & yes & $\begin{array}{c}\text { not } \\
\text { mated }\end{array}$ & no & $\begin{array}{c}\text { not } \\
\text { mated }\end{array}$ & no \\
$\begin{array}{l}\text { Recorded } \\
\text { pregnant } \\
\text { after mating }\end{array}$ & & & & & & & & \\
\hline
\end{tabular}

the first oestrus was not influenced by the weaning season.

The least squares means for the reproductive and other individual traits of the sows in the 4 different groups $(\mathrm{O}, \mathrm{S}$, NSO and $\mathrm{SO})$ are presented in Table 6 . Significant differences were found between the NSO and the SO sows. The $\mathrm{O}$ sows did not differ significantly from the SO sows. The S sows did not differ significantly from the NSO sows. The NSO sows had greater loss of weight and backfat during lactation than the SO sows.

Table 5. Mean values for weight and backfat loss during lactation and of litter size and litter weight gain in the SO sows. Correlations between these reproductive and other individual traits and the interval from weaning to first oestrus.

\begin{tabular}{|c|c|c|c|c|c|c|}
\hline & \multicolumn{5}{|c|}{ Interval from weaning to first oestrus } & \multirow{2}{*}{$\begin{array}{l}\text { Correlation } \\
\text { with interval }\end{array}$} \\
\hline & 4 & 5 & 6 & 7 & $8-10$ & \\
\hline Number of sows & 11 & 58 & 34 & 14 & 6 & \\
\hline $\begin{array}{l}\text { Weight loss } \\
\text { during } \\
\text { lactation (kg) }\end{array}$ & 25.0 & 32.0 & 36.4 & 40.3 & 38.3 & $\mathrm{r}=0.21^{*}$ \\
\hline $\begin{array}{l}\text { Weight loss: } \\
\% \text { of weight } \\
\text { at farrowing }\end{array}$ & 13.0 & 15.8 & 18.0 & 19.7 & 20.0 & $\mathrm{r}=0.24^{*}$ \\
\hline $\begin{array}{l}\text { Backfat loss } \\
\text { during } \\
\text { lactation }(\mathrm{mm})\end{array}$ & 8.1 & 8.8 & 8.2 & 9.6 & 7.8 & $\mathrm{r}=-0.02 \mathrm{n} . \mathrm{s}$. \\
\hline $\begin{array}{l}\text { Size of the } \\
\text { first litter }\end{array}$ & & & & & & \\
\hline - at birth & 8.9 & 9.8 & 11.1 & 10.6 & 11.7 & $r=0.22 *$ \\
\hline - at 3 weeks & 7.4 & 8.0 & 9.3 & 9.0 & 9.0 & $r=0.21^{*}$ \\
\hline $\begin{array}{l}\text { Weight gain } \\
\text { of the first litter, } \\
0-3 \text { weeks }(\mathrm{kg})\end{array}$ & 36.7 & 38.6 & 42.1 & 43.2 & 40.0 & $r=0.18^{*}$ \\
\hline
\end{tabular}


Table 6. Least squares means for the reproductive and other individual traits in the sows in the 4 different groups $(\mathrm{O}, \mathrm{S}, \mathrm{NSO}, \mathrm{SO})$.

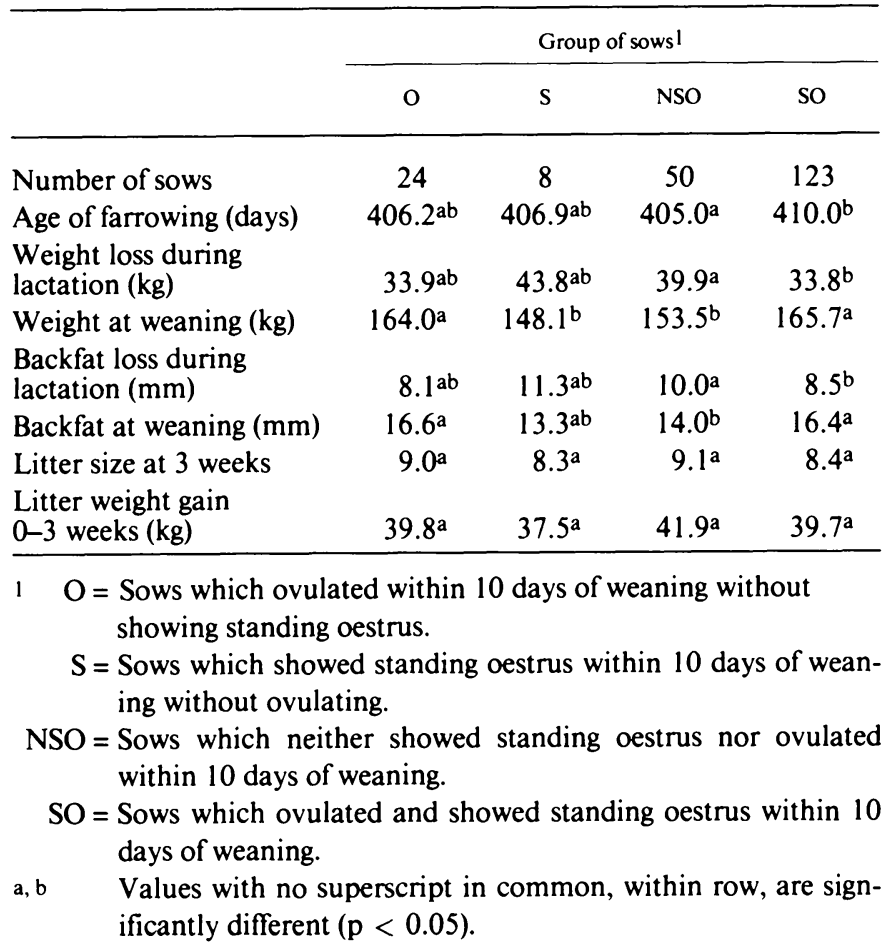

The NSO and SO sows have been used to describe the effect of relative weight loss during lactation on the ability to ovulate and to show standing oestrus. The results are presented in Fig. 2. There was a clear tendency towards the percentage of SO sows decreasing with increasing weight loss.

Litter size and litter weight gain influenced the relative weightloss in the sows. The correlation between weight loss and litter size at 3 weeks was $0.40(n=205, p \leq 0.001)$, and between weght loss and litter weight gain (0-3 weeks) 0.60 ( $p \leq 0.001)$. Sows with less than $10 \%$ weight loss $(n=37)$ had an average litter size of 7.3 piglets at 3 weeks and their mean litter weight gain from birth to 3 weeks of age was $32.2 \mathrm{~kg}$. The corresponding figures for sows with more than $30 \%$ weight loss $(n=10)$ was 9.4 piglets and $49.4 \mathrm{~kg}$. The variation in loss of weight and backfat was also great among sows with the same litter size (c.v. $=40 \%$ for sows with 9 piglets at 3 weeks). Sows with high farrowing weight lost more body weight during lactation, both in $\mathrm{kg}$ and in $\%$ of farrowing weight, than lighter sows. Sows with more backfat at farrowing lost more fat $(\mathrm{mm})$ during lactation than leaner sows. Older sows lost more weight and backfat during lactation than younger sows.

The weaning season had a large effect on ovulation and standing oestrus. The frequency of ovulating sows differed significantly between seasons ( $p \leq 0.001$, chisquare test). The lowest frequency of SO sows was found in the fourth quarter of the 


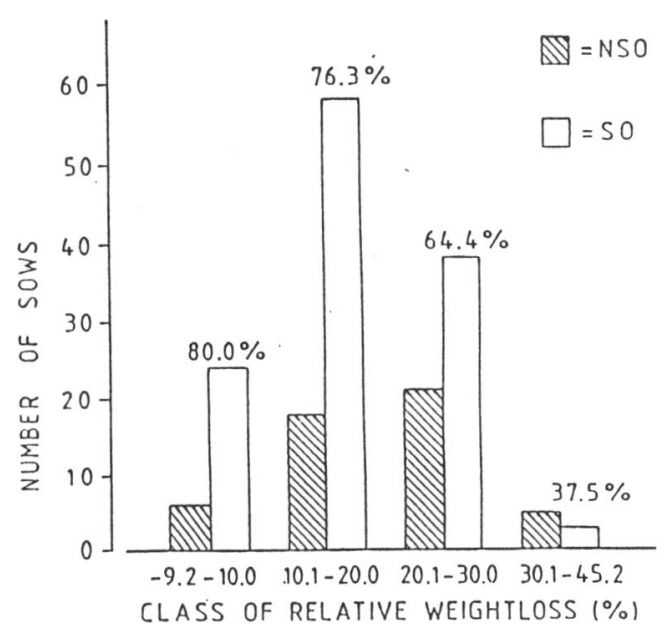

Figure 2. Number of NSO and SO sows in different classes of relative weight loss. Per cent of SO sows within class is presented.

See Table 6 for definitions.

year. The highest frequency of $\mathrm{O}$ sows was found in the second quarter. The results are presented in Fig. 3.

\section{Discussion}

In the present study, $60 \%$ of the 240 sows showed their first oestrus within 10 days of weaning. This result is in close agreement with some earlier reports on primiparous sows (Einarsson \& Settergren 1974, King 1978). Benjaminsen \& Karlberg (1981), on the other hand, found that $46 \%$ of 33 primiparous sows showed their first detected oestrus within 10 days of weaning. The results from these studies clearly show that a large proportion of primiparous sows express their first oestrus later than 10 days after weaning.

The distribution pattern of the first standing oestrus after weaning has been described in some earlier reports. Some authors have found 2 oestrous peaks, as in the present study (Benjaminsen \& Karlberg 1981), while others only report 1 peak (Karlberg 1980).

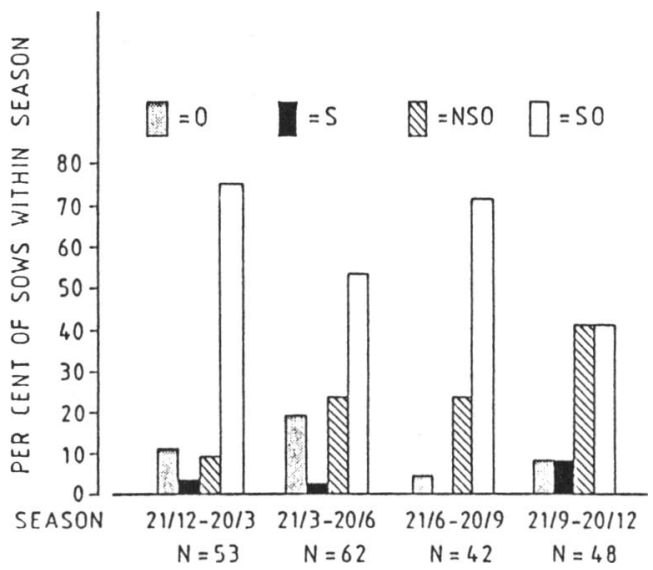

Figure 3. The effect of weaning season on ovulation and standing oestrus. Per cent of sows in each group within season is presented.

See Table 6 for definitions.

The second peak may represent sows which have ovulated without showing standing oestrus at their first oestrus after weaning. This theory is supported by the fact that the second oestrous peak occurred 24-30 days after weaning (Fig. 1).

In our study $12 \%$ of the sows ovulated without showing standing reflex within 10 days of weaning. Without progesterone measurements these sows would have been considered anoestrus. This underlines the importance of progesterone estimations in this type of study. Benjaminsen \& Karlberg (1981) found that ovulation without external signs of oestrus was more common among pluriparous than among primiparous sows.

Anovulatory standing oestrus occurred in $3.9 \%$ of the sows in the present study. The diagnosis was based on progesterone estimations. Very little has been reported in the literature on anovulatory oestrus in pigs. Benjaminsen \& Karlberg (1981) described 1 sow in their study without a rise in plasma progesterone at the expected time after mating. The only comprehensive study in this field has been carried out on gilts (Elias- 
son 1989). Eliasson found that $1.8 \%$ of the gilts had an anovulatory first oestrus. The oestrous symptoms were rather weak on these occasions. Further studies with very careful oestrous detection performed by trained technical personnel should be carried out to determine whether weak oestrous symptoms also occur at anovulatory oestrus in primiparous sows. At least half of the sows with an anovulatory first oestrus in our study ovulated at the following oestrus. The design of the present study, however, did not allow us to investigate whether all sows ovulated at the second oestrus after weaning or not.

In the present study a significant positive correlation was found among the SO sows between weight loss during lactation and IWO. Most other studies in this field have investigated the effect of different feeding regimes during lactation and found both differences in weight loss and in length of the IWO. A direct comparison with earlier studies is therefore not possible. Aherne \& Kirkwood (1985) showed in their review that sows losing less weight (high-fed sows) during lactation had a shorter IWO than sows losing more weight (low-fed sows). In the present study, no significant correlation was found between backfat loss during lactation and the IWO among the SO sows. These sows may have had a sufficient amount of body fat to regain ovarian cyclic activity after weaning. SO sows having a longer IWO nursed larger litters during their first lactation period than sows with a shorter IWO. This supports the findings of Fahmy et al. (1979). There was no significant correlation between the number of piglets born alive and the IWO: however, the correlation was significant between the number of piglets born and the IWO. The number of foetuses during gestation may therefore affect the subsequent interval from weaning to first oestrus.
Differences in reproductive and other individual traits were found, especially between the NSO and the SO sows in this study. The differences seem to be more evident between sows ovulating or not within 10 days of weaning than between sows showing standing oestrus or not within the same time. The NSO sows were 5 days younger than the SO sows at farrowing. This difference was significant, even though the sows were rather old at farrowing. The high farrowing age was due to the experimental design with rearing of animals in batches.

Loss of both body weight and backfat during lactation differed significantly between the NSO and the SO sows in the present study. Again it is difficult to compare these results with those of earlier studies, as they often used different feeding regimes during lactation. Reese et al. (1984) found in a study on lactation energy intake that low-fed sows which showed their first oestrus within 14 days of weaning had less weight and backfat loss during latation than low-fed sows which failed to express their first oestrus within that period of time. These results may indicate that a certain level of body weight and backfat is required to regain cyclic activity in the ovaries shortly after weaning.

The finding that the weaning season influences the ability to show oestrus and to ovulate within 10 days of weaning supports earlier Scandinavian studies (Benjaminsen \& Karlberg 1981). The number of SO sows was small during the second quarter of the year. This could be explained in part by the high frequency of sows ovulating without standing oestrus during this season. One reason for this problem may be weak oestrous symptoms during the spring. Further intensive studies of the oestrous symptoms are required to answer this question. Summer and autumn outdoor temperatures are relatively low in Sweden and are therefore not considered to be of any greater importance 
for the sows' ability to show standing oestrus and to ovulate after weaning (compare Stork 1979). According to several experimental studies, light is of major importance for the reproductive performance in sows. The great seasonal variations in daylight hours in Sweden are therefore likely to be one of the main factors causing seasonal variation in sows (compare gilts: Ehnvall et al. 1981).

The body weight loss during lactation in the sows in the present study can primarily be explained by the litter size and the litter weight gain. Danielsen \& Nielsen (1982) found a strong correlation between litter size and the sows' weight loss during lactation. The sows in our study were fed according to their litter size but the feed allowance was apparently insufficient. However, the litter size alone does not explain the change in weight and backfat during lactation, since there were great variations in loss of weight and backfat among sows nursing the same number of piglets.

The present study shows that:

- the distribution of the first standing oestrus had 2 peaks. The second peak occurred 24-30 days after weaning and probably represented sows which ovulated without showing standing oestrus at their first oestrus:

- ovulation without showing standing oestrus within 10 days of weaning ocurred in $12 \%$ of the sows and anovulatory oestrus in $4 \%$ of the sows:

- the sows which neither showed standing oestrus nor ovulated within 10 days of weaning lost more body weight and backfat during lactation than the sows which both showed standing oestrus and ovulated within 10 days of weaning:

- the weaning season influenced the ability to show standing oestrus and to vulate within 10 days of weaning:

- there were significant positive correlations between body weight loss during lactation, litter size, litter weight gain and the IWO in the sows which both showed standing oestrus and ovulated within 10 days of weaning.

\section{Acknowledgements}

This investigation was supported by The Farmer's Research Council for Information and Development.

The authors wish to thank Carina Ahlstedt, Susanne Hägg and Ulrica Bexelius for excellent technical assistance and the staff of the research station for taking such good care of the animals.

\section{References}

Aherne FX, Kirkwood RN: Nutrition and sow prolifacy. J. Reprod. Fert. 1985. Suppl. 33, 169183.

Aumaitre AJ, Legault C, Dagorn J, LeDenmat M: Influence of farm management and breed type on sows conception-weaning interval and productivity in France. Livestock Prod. Sci. 1976, 3, 75-83.

Benjaminsen E, Karlberg K: Postweaning oestrus and luteal function in primiparous and pluriparous sows. Res. Vet. Sci. 1981, 30, 318-322.

Bosu WTK, Edqvist L-E, Lindberg P, Martinsson $K$, Johansson $E D B$ : The effect of various dosages of lynestrenol on plasma levels of oestrogen and progesterone during the menstrual cycle in rhesus monkey. Contraception 1976, 13, 677-684.

Cole DJA, Varley MA, Hughes PE: Studies in sow reproduction. 2. The effect of lactation length on the subsequent reproductive performance of the sow. Anim. Prod. 1975, 20 , 401-406.

Danielsen $V$, Nielsen $H E$ : Søers vægt ændringer i relation til kuldnummer, race og kuldstørrelse. (The weightlosses in sows in relation with their litter number, race and littersize). Statens Husdyrbrugsforsøg 1982, June Number 415 .

$E^{\prime l} \cdot n v a l l ~ R$, Blomqvist $A$, Einarsson $S$, Karlberg $K$ : Culling of gilts with special references to reproductive failure. Nord. Vet.-Med. 1981, 33, 167-171. 
Einarsson S, Settergren I: Fertility and culling in some pig breeding herds in Sweden. Nord. Vet.-Med. 1974, 11, 427-442.

Eliasson L: A study on puberty and oestrus in gilts. J. Vet. Med. A 1989, 36, 46-54.

Fahmy MH, Holtmann WB, Baker RD: Failure to recycle after weaning, and weaning to oestrus interval in crossbred sows. Anim. Prod. 1979, 29, 193-202.

Karlberg $K$ : Factors affecting postweaning oestrus in the sow. Nord. Vet.-Med. 1980, 32, 185193.

King GJ: Occurrence of postweaning oestrus in primiparous and pluriparous sows. Proc., 5th Int. Pig Vet. Soc. Congr. 1978, Zagreb, paper K. A. 12.

King $R H$, Dunkin $A C$ : The effect of nutrition on the reproductive performance of first litter sows. 4 . The relative effects of energy and protein intakes during lactation on the performance of sows and their piglets. Anim. Prod. 1986, 43, 319-325.

Kunavongkrit A, Einarsson S, Settergren I: Follicular development in primiparous lactating sows. Anim. Reprod. Sci. 1982, 5, 47-56.

Reese DE, Moser BD, Peo Jr ER, Lewis AJ, Zimmerman $D R$, Kinder JE, Stroup $W W$ : Influence of energy intake during lactation on the interval weaning to first estrus in sows. J. Anim. Sci. 1982, 55, 590-598.

Reese DE, Peo Jr ER, Lewis AJ: Relationship of lactation energy intake and occurrence of postweaning estrus to body and backfat composition in sows. J. Anim. Sci. 1984, 58, 12361244.

Rojanasthien S, Einarsson S, Settergren I: Follicular development in lactating, postweaning and anoestrus primiparous sows. Acta vet. scand. 1987, 28, 421-427.

Rojanasthien $S$ : LH-patterns in jugular plasma and oestradiol-17 $\beta$ and progesterone in uteroovarian and jugular plasma of primiparous sows around weaning. J. Vet. Med. A 1988, 35, 498-505.
SAS Institute Inc.: SAS user's guide. Statistics Version 5. Cary, N. C. 1985.

Stern S: Performance testing of boars selected on diets with low or high protein level. 38th EAAP meetings Commission on pig production, Lisbon, Portugal 1987.

Stork $M G$ : Seasonal reproductive inefficiency in large pig breeding units in Britain. Vet. Rec. $1979,104,49-52$.

\section{Sammanfattning}

En studie av ungsuggornas förmåga att visa

brunst och ovulera efter avvänjningen.

Påverkan av vikt- och fettförluster under diperioden, kullstorlek, kulltillväxt samt årstid.

Förmågan att visa brunst och ovulera inom 10 dagar efter avvänjningen studerades hos 240 ungsuggor, alla utfodrade efter samma norm under diperioden. Suggorna vägdes och sidspäckets tjocklek mättes vid grisning och avvänjning. Brunstkontroll utfördes dagligen och blodprover för bestämning av plasma-progesteron togs regelbundet på 205 av suggorna.

Fördelningen av antal dagar till första brunst efter avvänjningen hade två toppar, den första inom 10 dagar och den andra 24-30 dagar efter avvänjningen.

Tolv procent av suggorna ovulerade inom $10 \mathrm{da}$ gar efter avvänjningen utan att visa brunst medan 4 procent hade en anovulatorisk första brunst.

Signifikanta skillnader i grisningsålder, vikt- och fettförluster under diperioden påvisades mellan de suggor som både visade brunst och ovulerade inom 10 dagar efter avvänjningen och de som varken visade brunst eller ovulerade inom samma tid. Årstiden vid avvänjningen visade sig ha ett signifikant inflytande på förmågan att visa brunst och ovulera inom 10 dagar efter avvänjningen.

Hos de suggor som både visade brunst och ovulerade inom 10 dagar efter avvänjningen sågs signifikant positiva korrelationer mellan viktförlust under diperioden, kullstorlek, kulltillväxt och intervallet mellan avvänjningen och första brunst.

(Received May 16, 1989; accepted October 5, 1989).

Reprints may be requested from: Marie Sterning, Department of Obstetrics and Gynaecology,

Faculty of Veterinary Medicine, Swedish University of Agricultural Sciences,

P. O. Box 7039, S-750 07 Uppsala, Sweden. 